\title{
Paul Pierre Lemercier de la Rivière, Pennsylvaniens et Féliciens. CEuvres utopiques (1771 et 1792)
}

\section{Simón Gallegos Gabilondo}

\section{(2) OpenEdition}

1 Journals

\section{Edizione digitale}

URL: http://journals.openedition.org/studifrancesi/467

DOI: $10.4000 /$ studifrancesi.467

ISSN: 2421-5856

\section{Editore}

Rosenberg \& Sellier

\section{Edizione cartacea}

Data di pubblicazione: 1 aprile 2015

Paginazione: 152-153

ISSN: 0039-2944

\section{Notizia bibliografica digitale}

Simón Gallegos Gabilondo, « Paul Pierre Lemercier de la Rivière, Pennsylvaniens et Féliciens. Euvres utopiques (1771 et 1792) », Studi Francesi [Online], 175 (LIX | I) | 2015, online dal 01 avril 2015, consultato il 18 septembre 2020. URL : http://journals.openedition.org/studifrancesi/467 ; DOI : https://doi.org/10.4000/studifrancesi.467

Questo documento è stato generato automaticamente il 18 settembre 2020.

\section{(c) 9 (i) $\Theta$}

Studi Francesi è distribuita con Licenza Creative Commons Attribuzione - Non commerciale - Non opere derivate 4.0 Internazionale. 


\title{
Paul Pierre Lemercier de la Rivière, Pennsylvaniens et Féliciens. Cuvres utopiques (1771 et 1792)
}

\author{
Simón Gallegos Gabilondo
}

\section{NOTIZIA}

PAUL PIERRE LEMERCIER DE LA RIVIÈRE, Pennsylvaniens et Féliciens. CEuvres utopiques (1771 et 1792), présentation et transcription par Bernard HERENCIA, Genève, Slatkine Érudition, 2014, pp. 443.

1 Tra i seguaci di François Quesnay, fondatore della fisiocrazia, Lemercier de la Rivière si distingue, non soltanto per essere stato amministratore coloniale e giurista, ma anche e soprattutto per aver articolato il suo pensiero in un'opera ampia e sistematica. I suoi scritti sono ormai accessibili grazie al consistente lavoro editoriale di Bernard HERENCIA, curatore dell'edizione critica delle opere di Lemercier de la Rivière in tre volumi. Dopo i primi due, Canevas d'un code constitutionnel. CEuvres politiques (1787-1789), e Liberté du commerce. CEuvres économiques (1765-1770), questo terzo volume raccoglie le opere utopiche Lettres d'Abraham Mansword (1771) e L'Heureuse Nation, ou Relations du gouvernement des Féliciens (1792). L'autore, la cui statura intellettuale attirò l'attenzione di Adam Smith o Caterina II di Russia, pur noto, rimane uno scrittore sconosciuto sotto vari aspetti, particolarmente per quanto riguarda l'interesse del suo contributo alla letteratura utopica e la complessità del legame di quest'ultima con il suo pensiero economico. 